\title{
Morfologi dan Klasifikasi Tanah Kebun Sere Wangi di Gayo Lues (Morphology and Soil Classification of Lemongrass Gardens in Gayo Lues)
}

\author{
Rizkon Zadidah Nasution, Manfarizah, Zainabun \\ ${ }^{1}$ Program Studi Ilmu Tanah, Fakultas Pertanian, Universitas Syiah Kuala \\ *Corresponding author: zainabun@ymail.com
}

\begin{abstract}
Abstrak. Tanaman sere wangi merupakan salah satu komoditas unggulan Kabupaten Gayo Lues yang saat ini terus menerus dikembangkan. Seiring peningkatan permintaan pasar para petani mulai tidak menanam tanpa memperhatikan kesesuaian lahannya, salah satu parameternya adalah jenis tanah. Penelitian ini bertujuan untuk mengetahui sifat-sifat morfologi dan klasifikasi tanah menurut Sistem Taksonomi Tanah di kebun sere wangi Kabupaten Gayo Lues sampai kategori subgrup. Metode yang digunakan yaitu survai deskriptif kuantitatif. Parameter yang diukur di lapangan berupa sifat morfologi diantaranya: warna dan kedalaman tanah. Di laboratorium berupa sifat fisika tanah adalah tekstur tanah, sifat kimia tanah yaitu C-organik dan kejenuhan basa serta kapasitas tukar kation. Hasil penelitian menunjukkan bahwa pedon I klasifikasi tanah Podsolik Coklat menjadi Ultisol adalah: (a) epipedon okrik karena memiliki warna terang value lembab > 3, C-organik memenuhi molik kecuali ketebalannya C-organik $\geq 0,6 \%(5,67 \%)$, kejenuhan basa $\leq 50 \%(10,48 \%)$ dan value serta chroma $\geq 3$ (value 4 dan chroma 3 ); (b) horison penciri bawah yang dijumpai adalah argilik karena mengandung liat $15-40 \%$, maka horison argilik 1,2 kali lebih banyak dari horison eluviasi; (c) subordo Humults, great group Haplohumults, subgroup Typic Haplohumults. Pedon II klasifikasi tanah Latosol menjadi Inceptisol adalah: (a) epipedon okrik karena memiliki warna terang value lembab > 3, C-organik memenuhi molik kecuali ketebalannya C-organik $\geq 0,6 \%$ (5,28\%), kejenuhan basa $\leq 50 \%(22,64 \%)$ dan value serta chroma $\geq 3$ (value 5 dan chroma 4); (b) horison penciri bawah yang dijumpai adalah kambik karena bertekstur pasir sangat halus/lebih halus warna lebih merah horison atas/bawahnya; (c) subordo Aquepts, great group Endoaquepts, subgroup Typic Endoaquepts.
\end{abstract}

Kata kunci: Sere wangi, Klasifikasi Tanah, Morfologi Tanah, Gayo Lues

\begin{abstract}
Lemongrass plant is one of the leading commodities of Gayo Lues Regency which is currently being continuously developed. As market demand increases, farmers begin not to plant without paying attention to the suitability of the land, one of the parameters is soil type. This study aims to determine the morphological characteristics and soil classification according to the Soil Taxonomy System in the Lemongrass Gardens, Gayo Lues Regency to the subgroup category. The method used is a quantitative descriptive survey. Parameters measured in the field are morphological characteristics including: color and soil depth. In the laboratory, the physical properties of soil are soil texture; Soil chemical properties are organic $\mathrm{C}$ and base saturation and cation exchange capacity. The results showed that pedon I of Podsolic Brown soil classification into Ultisols were: (a) ochric epipedon because it has a light color moist value > 3, C-organic meets mollic except the thickness of Corganic $0.6 \%(5.67 \%)$, base saturation 50\% (10.48\%) and value and chroma 3 (value 4 and chroma 3 ); (b) the lower characteristic horizon found is argillic because it contains $15-40 \%$ clay, so the argillic horizon is 1.2 times more than the eluvial horizon; (c) suborder Humults, great group Haplohumults, subgroup Typic Haplohumults. Pedon II soil classification of Latosols into Inceptisols are: (a) ochric epipedon because it has a light color moisture value > 3, C-organic meets mollic except the thickness of C-organic $0.6 \%$ (5.28\%), base saturation 50\% (22.64\%) and value and chroma 3 (value 5 and chroma 4); (b) the lower characteristic horizon found is kambik because the texture of the sand is very fine/fine, the color is redder, the upper/lower horizon; (c) suborder Aquepts, great group Endoaquepts, subgroup Typic Endoaquepts.
\end{abstract}

Keywords: Lemongrass, Soil Classification, Soil Morphology, Gayo Lues

\section{PENDAHULUAN}

Kabupaten Gayo Lues merupakan diantara satu sentra penghasil komoditas sere wangi di Provinsi Aceh. Sere wangi merupakan salah satu tanaman atsiri dari famili Graminae yang banyak di gunakan dalam berbagai industri. Tanah subur, gembur serta tinggi bahan organik contohnya Mediteran Kuning Coklat/ Coklat Berpasir sesuai pada sere wangi (Sumiartha et al., 2012). Data Bappeda Kabupaten Gayo Lues (2018), menunjukkan beberapa jenis tanah 
Kabupaten Gayo Lues berdasarkan sistem Dudal-Soepraptohardjo yaitu Aluvial, Andosol, Podsolik Coklat, Podsolik Merah Kuning, Latosol, dan Regosol.

Menentukan jenis tanah pada wilayah yang ditanami sere wangi diperlukan sifat-sifat tanah di lapangan dengan melihat morfologi tanah tersebut. Menurut Hardjowigeno (2003), morfologi tanah, yaitu pengamatan sifat-sifat tanah yang dapat diamati dan dipelajari di lapangan. Pengamatan dilakukan pada profil tanah yang baru dibuat. Pengamatan di lapangan dimulai dengan membedakan horison-horison tanah. Klasifikasi tanah merupakan suatu sistem pengaturan beberapa jenis tanah yang berbeda-beda tapi mempunyai sifat yang serupa ke dalam kelompok dan sub kelompok berdasarkan penggunaan (Das, 1995). Pengklasifikasian tanah dapat dilakukan dengan menggunakan Sistem Taksonomi Tanah dengan dua kategori yaitu tinggi dan rendah meliputi Ordo, Sub ordo, Great grup, Sub grup, Famili, dan Seri. Pengklasifikasian akhir didapat dengan menyesuaikan dengan keadaan morfologi tanah di lapangan dan dari hasil analisis akhir tanah di laboratorium (Panjaitan, 2015). Menurut Badan Perencanaan dan Pembangunan Aceh (2018), klasifikasi tanah di Gayo Lues hanya diteliti sampai pada tingkat ordo, sehingga harus diteliti lebih lanjut agar data klasifikasi tanah di Gayo Lues semakin lengkap dan data tersebut dapat digunakan untuk pertanian terutama pada tanaman sere wangi. Berdasarkan permasalahan tersebut perlu dilakukan penelitian lanjut mengenai morfologi dan klasifikasi tanah di kebun sere wangi pada beberapa kecamatan di Kabupaten gayo Lues.

Penelitian ini bertujuan untuk mengetahui sifat-sifat morfologi dan klasifikasi tanah menurut Sistem Taksonomi Tanah di kebun sere wangi Kabupaten Gayo Lues sampai kategori subgrup.

\section{METODE PENELITIAN}

Penelitian ini dilaksanakan di Kabupaten Gayo Lues, dan untuk analisis sampel tanah dilaksanakan di Laboratorium Kimia Tanah, Lab Fisika Tanah dan Lab tanah dan tanaman Fakultas Pertanian Unviersitas Syiah Kuala.

\section{MATERI DAN METODE}

\section{Metode Penelitian}

Pada penelitian Penelitian ini menggunakan metode survei dan analisis deskrifif. Pada tahap awal penelitian dilakukan persiapan meliputi pengumpulan data yang berkaitan dengan daerah penelitian. Data sekunder tersebut digunakan sebagai acuan dalam pembuatan batasbatas satuan peta lahan.

Sampel tanah akan di ambil pada dua pedon, dan di setiap horison sampel tanah diambil $1 \mathrm{~kg}$ untuk keperluan analisi sifat fisika dan kimia di Lab, kedua pedon terletak di Kecamatan Pining dan Kecamatan Dbun Gelang. Morfologi tanah di lapang diamati sifat-sifatnya yang meliputi: batas-batas horison, warna, tekstur, struktur, konsistensi, pori-pori tanah (void), perakaran tanah, konkresi/nodul, dan $\mathrm{Ph}$. Tanah di lokasi penelitian diklasifikasikan dan mendukung klasifikasi tanahnya adalah dengan melihat sifat morfologi dan hasil laboratorium. Sistem klasifikasi tanah yang digunakan adalah Sistem Taksonomi Tanah menurut USDA dengan menggunakan Kunci Taksonomi Tanah. 


\section{HASIL DAN PEMBAHASAN}

\section{Sifat Morfologi Pedon-pedon di Lapangan} Tabel 1

Hasil pengamatan sifat-sifat morfologi tanah pada pedon di lapangan disajikan pada

Tabel 1. Sifat Morfologi Tanah di Lapangan

\begin{tabular}{|c|c|c|c|c|c|c|c|c|c|c|}
\hline \multirow{3}{*}{$\begin{array}{c}\text { Horison/ } \\
\text { Kedalaman } \\
(\mathrm{cm})\end{array}$} & \multirow{3}{*}{$\begin{array}{c}\text { Batas } \\
\text { Lap. }\end{array}$} & \multirow{3}{*}{$\begin{array}{l}\text { Batas } \\
\text { Topo. }\end{array}$} & \multirow{3}{*}{$\begin{array}{c}\text { Warna } \\
\text { Matriks } \\
\text { Tanah }\end{array}$} & \multirow{3}{*}{$\begin{array}{c}\text { Struktur } \\
\text { Tanah }\end{array}$} & \multicolumn{2}{|c|}{ Konsistensi } & \multirow{2}{*}{\multicolumn{2}{|c|}{$\begin{array}{c}\text { Akar } \\
\text { Tanaman }\end{array}$}} & \multirow{3}{*}{$\mathrm{BO} \mathrm{T}$} & \multirow{3}{*}{$\mathrm{K} \mathrm{T}$} \\
\hline & & & & & \multirow{2}{*}{ B } & \multirow{2}{*}{$\mathrm{L}$} & & & & \\
\hline & & & & & & & $\mathrm{H}$ & $\mathrm{K}$ & & \\
\hline \multicolumn{11}{|c|}{ Pedon I } \\
\hline $\mathrm{O}(0-15)$ & $\mathrm{b}$ & o & $10 \mathrm{YR} 3 / 4$ & $\mathrm{r}, \mathrm{lm}, \mathrm{sh}$ & tlk & sgb & ba & - & ti & ta \\
\hline$A(15-65)$ & $\mathrm{b}$ & o & $10 \mathrm{YR}$ 4/6 & $\mathrm{r}, \mathrm{lm}, \mathrm{sh}$ & alk & sgb & ba & - & ti & sd \\
\hline $\mathrm{Bt}_{1}(65-135)$ & $\mathrm{b}$ & o & 10 YR 5/6 & gs,sd,sd & alk & $\operatorname{tg}$ & $\mathrm{sd}$ & - & ta & sd \\
\hline $\mathrm{Bt}_{2}(135-160)$ & $\mathrm{b}$ & 1 & $5 \mathrm{YR} 4 / 6$ & $\mathrm{pr}, \mathrm{sd}, \mathrm{bs}$ & alk & $\operatorname{tg}$ & sdkt & - & sd & ta \\
\hline \multicolumn{11}{|c|}{ Pedon IV } \\
\hline $\mathrm{O}(0-8)$ & $\mathrm{a}$ & 1 & 10 YR 3/1 & $\mathrm{g}, \mathrm{ku}, \mathrm{bs}$ & spl & $\operatorname{tg}$ & ba & sdkt & ti & ta \\
\hline $\mathrm{A}(8-41)$ & $\mathrm{b}$ & o & 10 YR 5/4 & gs,ku,bs & alk & stg & ba & - & ti & ta \\
\hline B $(41-92)$ & $\mathrm{b}$ & o & $5 Y 8 / 3$ & $\mathrm{~g}, \mathrm{ku}, \mathrm{bs}$ & alk & stg & ba & - & ti & $\mathrm{sd}$ \\
\hline $\mathrm{BC}(92-161)$ & $\mathrm{b}$ & o & 10 YR 5/1 & gs,ku,bs & slk & stg & sdkt & - & $\mathrm{ti}$ & sd \\
\hline \multicolumn{11}{|c|}{ 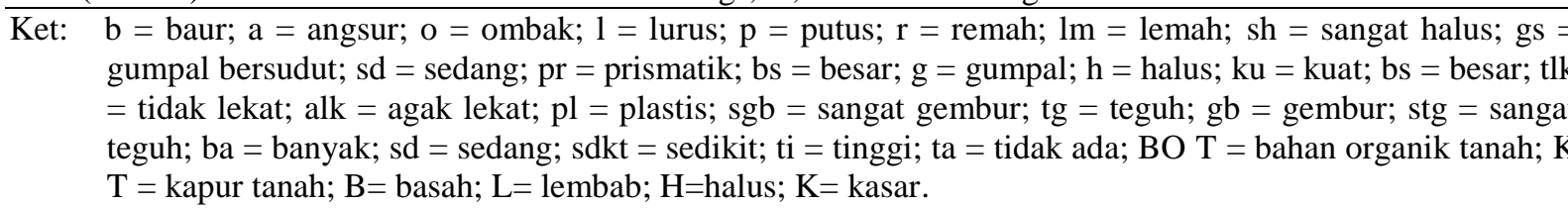 } \\
\hline
\end{tabular}

\section{Pedon I}

Pedon I mempunyai ketebalan solum $160 \mathrm{~cm}$. Terdiri atas empat horison yakni horison O $(0-15 \mathrm{~cm})$ memiliki warna Dark Yellowish Brown (10 YR 3/4), tipe struktur tanahnya adalah remah. Remah dicirikan dengan membulat, sangat porous, dan agregatnya tidak terikat sesamanya. Tingkat perkembangannya lemah, yaitu butir struktur dapat dilihat tapi mudah rusak dan hancur waktu di ambil dari profil untuk diperiksa. Ukuran strukturnya adalah sangat halus dengan ukuran $0,1 \mathrm{~cm}$. Untuk konsistensi basah adalah tidak lekat, akan tetapi konsistensi lembab untuk pada lapisan adalah sangat gembur. Tidak dijumpai bahan kasar dan dijumpai akar tanaman halus sampai kedalaman $71 \mathrm{~cm}$. Kandungan bahan organiknya tinggi dan tidak dijumpai kapur pada horison ini.

Horison A $(15-65 \mathrm{~cm})$ memiliki warna Dark Yellowish Brown (10 YR 4/6), tipe struktur tanahnya adalah remah, dicirikan dengan membulat, sangat porous, dan agregatnya tidak terikat sesamanya. Tingkat perkembangannya lemah, yaitu butir struktur dapat dilihat tapi mudah rusak dan hancur waktu di ambil dari profil untuk diperiksa. Ukuran strukturnya adalah sangat halus dengan ukuran $0,1 \mathrm{~cm}$, konsistensi basah agak lekat dan konsistensi lembab pada horison ini adalah sangat gembur. Tidak dijumpai bahan kasar dan dijumpai akar tanaman halus. Kandungan bahan organiknya tinggi, dan kandungan kapurnya sedang.

Horison B $(65-135 \mathrm{~cm})$ memiliki warna Yellowish Brown $(10 \mathrm{YR}$ /6). Tipe struktur tanahnya adalah gumpal bersudut, gumpal bersudut dicirikan dengan sumbu vertikal sama dengan sumbu horizontal, sisinya membentuk sudut tajam. Tingkat perkembangannya sedang, yaitu butir-butir struktur agak kuat dan tidak hancur waktu diambil dari profil untuk diperiksa. Ukuran strukturnya adalah sedang dengan ukuran $1-2 \mathrm{~cm}$. Konsistensi basah membentuk gulungan tanah lebih $1 \mathrm{~cm}$, sehingga diperlukan sedikit tekanan untuk merusak gulungan tersebut atau disebut plastis, konsistensi lembab pada lapisan adalah teguh. Tidak 
dijumpai bahan kasar dan dijumpai akar tanaman halus. Tidak dijumpai kandungan bahan organik pada horison ini, dan kandungan kapurnya sedang.

Horison BC $(135-160 \mathrm{~cm})$ memiliki warna Yellowish Red $(5 \mathrm{YR}$ /6). Tipe struktur tanahnya adalah prismatik, dicirikan dengan sumbu vertikal lebih berkembang dari sumbu horizontal, sisi atas datar. Tingkat perkembangannya sedang, yaitu butir-butir struktur agak kuat dan tidak hancur waktu diambil dari profil untuk diperiksa. Ukuran strukturnya adalah besar dengan ukuran $5-10 \mathrm{~cm}$. Konsistensi basah ialah agak lekat, konsistensi lembab di lapisan ialah teguh, dikatakan teguh adalah memerlukan tekanan lebih besar untuk menghancurkan tanah tersebut. Tidak dijumpai bahan kasar dan dijumpai akar tanaman halus, kandungan bahan organiknya sedang dan tidak dijumpai kapur pada horison ini.

\section{Pedon II}

Pedon II mempunyai ketebalan solum $161 \mathrm{~cm}$, terdiri atas empat horison yakni horison $\mathrm{O}(0-8 \mathrm{~cm})$ memiliki warna Very Dark Grey $\left(10 \mathrm{YR}^{3} / 1\right)$. Bentuk struktur tanahnya adalah gumpal, dicirikan dengan sumbu vertikal sama dengan sumbu horizontal, sisinya membentuk sudut bulat. Tingkat perkembangannya kuat, dicirikan dengan butir struktur kuat, tidak rusak walaupun digerakkan. Ukuran strukturnya adalah besar dengan ukuran 2 - $5 \mathrm{~cm}$. Konsistensi basah adalah sangat plastist, dikatakan sangat plastis yaitu diperlukan tekanan besar untuk merusak gulungan yang terbentuk, lapisan ini memiliki konsistensi teguh, diperlukan tekanan yang lebih besar untuk menghancurkan tanah tersebut. Kandungan bahan organiknya tinggi dan tidak dijumpai kapur pada horison ini.

Horison A $(8-41 \mathrm{~cm})$ memiliki warna Yellowish Brown $(10 \mathrm{YR} 5 / 4)$. Bentuk struktur tanahnya adalah gumpal bersudut, dicirikan dengan sumbu vertikal sama dengan sumbu horizontal, sisinya membentuk sudut tajam. Tingkat perkembangannya kuat, dicirikan dengan butir strukturnya kuat, tidak rusak walaupun digerakkan. Ukuran strukturnya adalah besar dengan ukuran $2-5 \mathrm{~cm}$. Konsistensi basah adalah agak lekat, dikatakan agak lekat yaitu sedikit melekat pada jari tangan atau benda lain, pada lapisan memliki konsistensi keadaan lembab yaitu teguh. Kandungan bahan organiknya tinggi dan tidak dijumpai kapur pada horison ini.

Horison B (41 - $92 \mathrm{~cm})$ memiliki warna Palc Yellow $\left(5^{\mathrm{Y}}\right.$ 8/3). Bentuk struktur tanahnya adalah gumpal, dicirikan dengan sumbu vertikal sama dengan sumbu horizontal, sisinya membentuk sudut bulat. Tingkat perkembangannya kuat, dicirikan dengan butir strukturnya kuat, tidak rusak walaupun digerakkan. Ukuran strukturnya adalah besar dengan ukuran $2-5 \mathrm{~cm}$. Konsistensi basah adalah agak lekat, dikatakan agak lekat yaitu sedikit melekat pada jari tangan atau benda lain, konsistensi pada situasi lembab di lapisan ini ialah sangat teguh. Kandungan bahan organiknya tinggi, dan kandungan kapurnya sedang.

Horison BC $(92-161 \mathrm{~cm})$ memiliki warna Gray $(10 \mathrm{YR}$ 5/1). Bentuk struktur tanahnya adalah gumpal bersudut, dicirikan dengan sumbu vertikal sama dengan sumbu horizontal, sisinya membentuk sudut tajam. Tingkat perkembangannya kuat, dicirikan dengan butir strukturnya kuat, tidak rusak walaupun digerakkan. Ukuran strukturnya adalah besar dengan ukuran $2-5 \mathrm{~cm}$. Konsistensi basah adalah sangat lekat, dikatakan sangat lekat yaitu sangat melekat pada jari tangan atau benda lain, konsistensi lembab pada horison ini adalah sangat teguh, dikatakan sangat teguh adalah adalah memerlukan tekanan yang sangat besar sampai

sama sekali tanah tidak bisa dihancurkan. Kandungan bahan organiknya tinggi, dan kandungan kapur sedang.

\section{Sifat Fisika Tanah}

Adapun sifat fisika tanah yang sudah dianalisis di Laboratorium disajikan pada Tabel 2. 
Tabel 2. Hasil Analisis Tekstur Tanah dan Bulk Density

\begin{tabular}{lccccc}
\hline $\begin{array}{c}\text { Horison/ } \\
\text { Kedalaman } \\
(\mathrm{cm})\end{array}$ & \multicolumn{3}{c}{ Tekstur Tanah } & Kelas Tekstur & Bulk Density $\left(\mathrm{g} \mathrm{cm}^{-3}\right)$ \\
\cline { 2 - 4 } & Pasir (\%) & Debu (\%) & Liat (\%) & & \\
\hline $\mathrm{O}(0-15)$ & 52 & 12 & 36 & Liat berpasir & 0,931 \\
$\mathrm{~A}(15-65)$ & 24 & 68 & 8 & Lempung berdebu & 1,537 \\
$\mathrm{~B}_{\mathrm{t} 1}(65-135)$ & 39 & 23 & 38 & Lempung berliat & \\
\hline & & & Pedon II & & 1,481 \\
\hline $\mathrm{O}(0-8)$ & 37 & 21 & 42 & Liat & 1,557 \\
$\mathrm{~A}(18-41)$ & 25 & 25 & 50 & Liat & \\
$\mathrm{B}(41-92)$ & 26 & 30 & 44 & Liat & \\
\hline
\end{tabular}

\section{Pedon I}

Horison O mempunyai bobot isi atau Bulk Density tanah $<0,9 \mathrm{~g} \mathrm{~cm}^{-3}$. Tekstur tanah yang dijumpai pada horison $\mathrm{O}$ adalah liat berpasir, distribusi ukuran butir didominasi oleh fraksi pasir dengan jumlah persentase 52\%, kemudian diikuti fraksi liat 36\% dan fraksi debu $12 \%$. Horison A mempunyai bobot isi atau Bulk Density tanah $<1,5 \mathrm{~g} \mathrm{~cm}^{-3}$. Tekstur tanah yang dijumpai pada horison A adalah lempung berdebu, distribusi ukuran butir didominasi oleh fraksi debu dengan jumlah persentase $68 \%$, kemudian diikuti fraksi pasir $24 \%$ dan fraksi liat $8 \%$. Tekstur tanah yang dijumpai pada horison B adalah lempung berliat, distribusi ukuran butir didominasi oleh fraksi pasir dengan jumlah persentase $39 \%$, kemudian diikuti fraksi liat $38 \%$ dan fraksi debu $23 \%$.

\section{Pedon II}

Horison O mempunyai bobot isi atau Bulk Density tanah $1,4 \mathrm{~g} \mathrm{~cm}^{-3}$. Tekstur tanah yang dijumpai pada horison $\mathrm{O}$ adalah liat, distribusi ukuran butir didominasi oleh fraksi liat dengan jumlah persentase $42 \%$, kemudian diikuti fraksi pasir $37 \%$ dan fraksi debu $21 \%$. Horison A mempunyai bobot isi atau Bulk Density tanah $1,5 \mathrm{~g} \mathrm{~cm}^{-3}$. Tekstur tanah yang dijumpai pada horison A adalah liat, distribusi ukuran butir didominasi oleh fraksi liat dengan jumlah persentase 50\%, kemudian diikuti fraksi pasir dan debu memiliki persentase yang sama yaitu 25\%. Horison B memiliki tekstur tanah liat, distribusi ukuran butir didominasi oleh liat dengan jumlah persentase $44 \%$, kemudian diikuti fraksi debu $30 \%$ dan fraksi pasir $26 \%$.

\section{Sifat Kimia Tanah \\ Pedon I}

Penelitian ini untuk pengukuran $\mathrm{pH}$ tanah menggunakan dua pengukuran, yaitu menggunakan $\mathrm{H}_{2} \mathrm{O}$ dan $\mathrm{KCl}$. Nilai $\mathrm{pH} \mathrm{H}_{2} \mathrm{O}$ pada horison $\mathrm{O}$ adalah 4,60 (masam) dan nilai $\mathrm{pH}$ $\mathrm{KCl}$ sebesar 4,45 (netral). Horison ini memiliki kandungan C-organik sebesar 16,68\% (sangat tinggi). Kandungan $\mathrm{Ca} \mathrm{dd}=2,24 \mathrm{cmol} \mathrm{kg}^{-1}$ (rendah), $\mathrm{Mg} \mathrm{dd}=0,39 \mathrm{cmol} \mathrm{kg}^{-1}$ (sangat rendah), $\mathrm{K}$ dd $=0,27 \mathrm{cmol} \mathrm{kg}^{-1}$ (rendah), nilai $\mathrm{Na} \mathrm{dd}=0,22 \mathrm{cmol} \mathrm{kg}^{-1}$, (rendah). Horison ini memiliki nilai KTK 22,80 $\mathrm{cmol} \mathrm{kg}^{-1}$ (sedang), KTK liat pada horison ini $=157,89 \mathrm{me} / 100$ liat, dan Kejenuhan Basa $=13,66 \%$ (sangat rendah).

Nilai $\mathrm{pH} \mathrm{H}_{2} \mathrm{O}$ pada horison A adalah 4,84 (masam), kemudian nilai $\mathrm{pH} \mathrm{KCl}=5,25$ (netral). Kandungan C-organik $=5,67 \%$ (sangat tinggi). Kandungan $\mathrm{Ca} \mathrm{dd}=2,04 \mathrm{cmol} \mathrm{kg}^{-1}$ (rendah), $\mathrm{Mg} \mathrm{dd}=0,16 \mathrm{cmol} \mathrm{kg}{ }^{-1}$ (sangat rendah), $\mathrm{K} \mathrm{dd}=0,19 \mathrm{cmol} \mathrm{kg}^{-1}$ (rendah), $\mathrm{Na} \mathrm{dd=}$ $0,21 \mathrm{cmol} \mathrm{kg}^{-1}$ (rendah). Horison ini memiliki nilai KTK $24,80 \mathrm{cmol} \mathrm{kg}^{-1}$ dan $\mathrm{KTK}$ liat $=$ 
32,25 me/100 liat (tinggi), kemudian horison ini memiliki Kejenuhan Basa sebesar 10,46\% (sangat rendah).

Nilai $\mathrm{pH} \mathrm{H}_{2} \mathrm{O}$ pada horison $\mathrm{B}$ adalah 5,14 (masam), kemudian nilai $\mathrm{pH} \mathrm{KCl}$ sebesar 4,71 (netral). Horison ini memiliki kandungan C-organik sebesar 0,24\% (rendah). Pada horison B menunjukkan bahwa kandungan Ca dapat ditukar adalah $2,27 \mathrm{cmol} \mathrm{kg}^{-1}$ (rendah) karena kelas rendah memiliki nilai sebesar 2,0 - 5,00 $\mathrm{cmol} \mathrm{kg}^{-1}$. Kandungan $\mathrm{Mg}$ dapat ditukar adalah 0,20 cmol kg-1, tergolong ke dalam kelas sangat rendah karena $<0,30 \mathrm{cmol} \mathrm{kg}^{-1}$, kemudian kandungan $\mathrm{K}$ dapat ditukar adalah sebesar $0,12 \mathrm{cmol} \mathrm{kg}^{-1}$, tergolong ke dalam kelas sangat tinggi karena nilai yang terkandung sudah melebihi kriteria penilaian sangat tinggi memiiki nilai $>1,0 \mathrm{cmol} \mathrm{kg}{ }^{-1}$. Terakhir adalah nilai $\mathrm{Na}$ dapat ditukar sebesar $0,28 \mathrm{cmol} \mathrm{kg}^{-1}$, tergolong kedalam kelas (rendah) dikarenakan mempunyai angka diantara $0,1-0,3 \mathrm{cmol} \mathrm{kg}^{-1}$. Horison ini memiliki nilai KTK 23,60 $\mathrm{cmol} \mathrm{kg}^{-1}$ dan KTK liat pada horison ini sebesar 161,01 me/100 liat, kemudian horison ini memiliki Kejenuhan Basa sebesar 12,16\% dan ini tergolong ke dalam kategori sedang karena nilai yang dimiliki berkisar antara 41\% - 60\%.

$\underline{\text { Sifat kimia tanah yang sudah dianalisis di Laboratorium di sajikan pada Tabel } 3 .}$

\begin{tabular}{|c|c|c|c|c|c|c|c|c|c|c|c|c|}
\hline \multirow{2}{*}{$\begin{array}{l}\text { Horison/ } \\
\text { Kedalaman } \\
\quad(\mathrm{cm})\end{array}$} & \multicolumn{2}{|c|}{$\begin{array}{c}\text { Reaksi } \\
\text { Tanah (pH) }\end{array}$} & \multirow[t]{2}{*}{ BO } & \multirow[t]{2}{*}{$\begin{array}{l}\mathrm{CO} \\
(\%)\end{array}$} & \multicolumn{4}{|c|}{$\begin{array}{l}\text { Basa-basa dd } \\
\left(\mathrm{cmol} \mathrm{kg}^{-1}\right)\end{array}$} & \multicolumn{2}{|c|}{$\begin{array}{c}\text { Kemasaman } \\
\text { Potensial } \\
\left(\mathrm{cmol} \mathrm{kg}^{-1}\right)\end{array}$} & \multirow[t]{2}{*}{ KTK } & \multirow[t]{2}{*}{$\begin{array}{c}\mathrm{KB} p \mathrm{pH} \\
7(\%)\end{array}$} \\
\hline & $\mathrm{H}_{2} \mathrm{O}$ & $\mathrm{KCl}$ & & & $\mathrm{Ca}$ & $\mathrm{Mg}$ & K & $\mathrm{Na}$ & $\mathrm{Al}$ & $\mathrm{H}$ & & \\
\hline \multicolumn{13}{|c|}{ Pedon I } \\
\hline $\mathrm{O}(0-15)$ & 4,60 & 4,45 & 28,75 & 16,68 & 2,24 & 0,39 & 0,27 & 0,22 & - & - & 22,80 & 13,68 \\
\hline A (15-65) & 4,84 & 5,25 & 9,77 & 5,67 & 2,04 & 0,16 & 0,19 & 0,21 & - & - & 24,80 & 10,48 \\
\hline $\mathrm{Bt}_{1}(65-135)$ & 5,14 & 4,71 & 0,41 & 0,24 & 2,27 & 0,20 & 0,12 & 0,28 & - & - & 23,60 & 12,16 \\
\hline \multicolumn{13}{|c|}{ Pedon IV } \\
\hline $\mathrm{O}(0-8)$ & 6,02 & 5,88 & 7,91 & 4,59 & 4,40 & 0,41 & 0,20 & 0,52 & - & - & 21,60 & 25,60 \\
\hline A $(8-41)$ & 5,66 & 5,24 & 9,10 & 5,28 & 3,76 & 0,42 & 0,13 & 0,49 & 0,56 & tu & 21,20 & 22,64 \\
\hline B (41-92) & 5,66 & 4,81 & 7,39 & 4,29 & 3,44 & 0,42 & 0,12 & 0,47 & 0,64 & $\mathrm{tu}$ & 21,60 & 20,60 \\
\hline
\end{tabular}

Keterangan : tu $=$ tidak terukur; KTK = Kapasitas Tukar Kation; KTK E = Kapasitas Tukar Kation Efektif;

\section{Pedon II}

Nilai $\mathrm{pH} \mathrm{H}_{2} \mathrm{O}$ pada horison $\mathrm{O}$ adalah 4,25 (sangat masam), dan nilai $\mathrm{pH} \mathrm{KCl}$ sebesar 3,84 dan (kelas masam). Horison ini memiliki kandungan C-organik sebesar 4,59\%, digolongkan ke dalam kelas tinggi karena nilai yang dimiliki berkisar 3,01 - $5 \%$. Pada horison $\mathrm{O}$ menunjukkan bahwa kandungan $\mathrm{Ca}$ dapat ditukar adalah $4,40 \mathrm{cmol} \mathrm{kg}^{-1}$ dan dikategorikan kedalam kelas rendah karena, kelas rendah memiliki nilai sebesar 2,0 - 5,00 cmol kg . Kandungan $\mathrm{Mg}$ dapat ditukar adalah $0,41 \mathrm{cmol} \mathrm{kg}^{-1}$, tergolong kedalam kelas rendah karena 0,4-1,00 $\mathrm{cmol} \mathrm{kg}^{-1}$, kemudian kandungan $\mathrm{K}$ dapat ditukar adalah sebesar 0,20 $\mathrm{cmol} \mathrm{kg}^{-1}$, tergolong kedalam kelas rendah karena nilai yang terkandung berkisar antara 0,10 $-0,30 \mathrm{cmol} \mathrm{kg}^{-1}$. Terakhir adalah nilai $\mathrm{Na}$ dapat ditukar sebesar $0,52 \mathrm{cmol} \mathrm{kg}^{-1}$, tergolong ke dalam kelas sedang yaitu diantara $0,40-0,50 \mathrm{cmol} \mathrm{kg}^{-1}$. Horison ini memiliki nilai KTK $21,60 \mathrm{cmol} \mathrm{kg}^{-1}$, nilai tersebut termasuk sedang dengan kisaran nilai $17-24 \mathrm{cmol} \mathrm{kg}^{-1} \mathrm{KTK}$ liat pada horison ini sebesar 250,00 me/100 liat, kemudian horison ini memiliki Kejenuhan Basa sebesar 25,60\% dan ini tergolong kedalam kategori rendah karena nilai yang dimiliki berkisar antara $20 \%-40 \%$. 
Nilai $\mathrm{pH} \mathrm{H}_{2} \mathrm{O}$ pada horison $\mathrm{A}$ adalah 4,64 (masam), $\mathrm{pH} \mathrm{KCl}$ sebesar 3,95 (masam). Kandungan C-organik sebesar 5,28\%, (sangat tinggi karena > 5\%). Kandungan $\mathrm{Ca} d d=3,76$ $\mathrm{cmol} \mathrm{kg}^{-1}$ dan (renda, kelas rendah nilai 2,0 - 5,00 $\mathrm{cmol} \mathrm{kg}^{-1}$ ). Kandungan $\mathrm{Mg}$ dapat dd = 0,42 cmol kg-1 (kelas rendah karena nilainya berkisar antara $0,40-1,00 \mathrm{cmol} \mathrm{kg}{ }^{-1}$ ), kemudian kandungan $\mathrm{K}$ dd $=0,13 \mathrm{cmol} \mathrm{kg}^{-1}$ (rendah $0,10-0,30 \mathrm{cmol} \mathrm{kg}^{-1}$ ). Terakhir adalah nilai $\mathrm{Na}$ dapat ditukar sebesar $0,49 \mathrm{cmol} \mathrm{kg}^{-1}$, tergolong ke dalam kelas sedang, diantara $0,40-0,50$ $\mathrm{cmol} \mathrm{kg}^{-1}$. Horison ini memiliki nilai KTK $21,20 \mathrm{cmol} \mathrm{kg}^{-1}$ dan nilai tersebut masuk ke dalam kelas sedang dengan kisaran nilai $17-24 \mathrm{cmol} \mathrm{kg}^{-1}$, sedangkan KTK liat pada horison ini sebesar 8,77 me/100 liat, kemudian horison ini memiliki Kejenuhan Basa sebesar 22,64\% dan ini tergolong ke dalam kategori rendah karena nilai yang dimiliki berkisar antara $20 \%-40 \%$.

Nilai $\mathrm{pH} \mathrm{H}_{2} \mathrm{O}$ pada horison $\mathrm{B}$ adalah 4,85 (masam), dan nilai $\mathrm{pH} \mathrm{KCl}$ sebesar 3,99 (masam). Horison ini memiliki kandungan C-organik sebesar 4,29\%, digolongkan ke dalam kelas tinggi karena nilai yang dimiliki berkisar 3,01 - 5\%. Pada horison B menunjukkan bahwa kandungan Ca dapat ditukar adalah $3,44 \mathrm{cmol} \mathrm{kg}^{-1}$ dan termasuk rendah karena, kelas rendah memiliki nilai sebesar 2,0 - 5,00 $\mathrm{cmol} \mathrm{kg}^{-1}$. Kandungan $\mathrm{Mg}$ dapat ditukar adalah $0,42 \mathrm{cmol} \mathrm{kg}^{-1}$, tergolong ke dalam kelas rendah karena $0,4-1,00 \mathrm{cmol} \mathrm{kg}^{-1}$, kemudian kandungan $\mathrm{K}$ dapat ditukar adalah sebesar $0,12 \mathrm{cmol} \mathrm{kg}^{-1}$, tergolong kedalam kelas rendah karena nilai yang terkandung berkisar antara $0,10-0,30 \mathrm{cmol} \mathrm{kg}^{-1}$. Terakhir adalah nilai $\mathrm{Na}$ dapat ditukar sebesar $0,47 \mathrm{cmol} \mathrm{kg}^{-1}$, tergolong ke dalam kelas sedang dengan angka $0,40-0,50 \mathrm{cmol} \mathrm{kg}^{-1}$. Horison ini memiliki nilai KTK 21,60 $\mathrm{cmol} \mathrm{kg}^{-1}$ dan nilai tersebut merupakan sedang dengan kisaran nilai $17-24 \mathrm{cmol} \mathrm{kg}^{-1} \mathrm{KTK}$ liat pada horison ini sebesar 165,17 me/100 liat, kemudian horison ini memiliki Kejenuhan Basa sebesar 20,60\% dan ini tergolong ke dalam kategori rendah karena nilai yang dimiliki berkisar antara $20 \%-40 \%$.

\section{Klasifikasi Tanah}

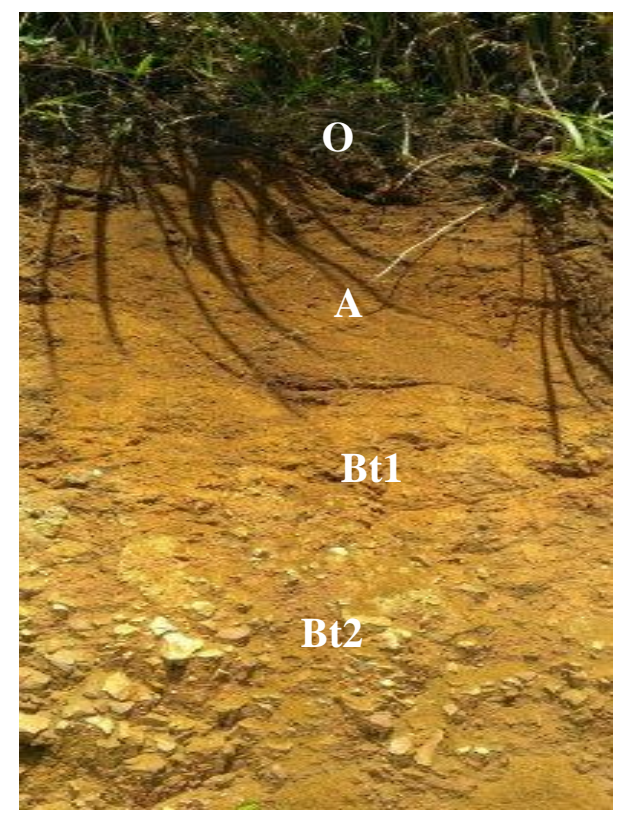

Gambar 1. Pedon I

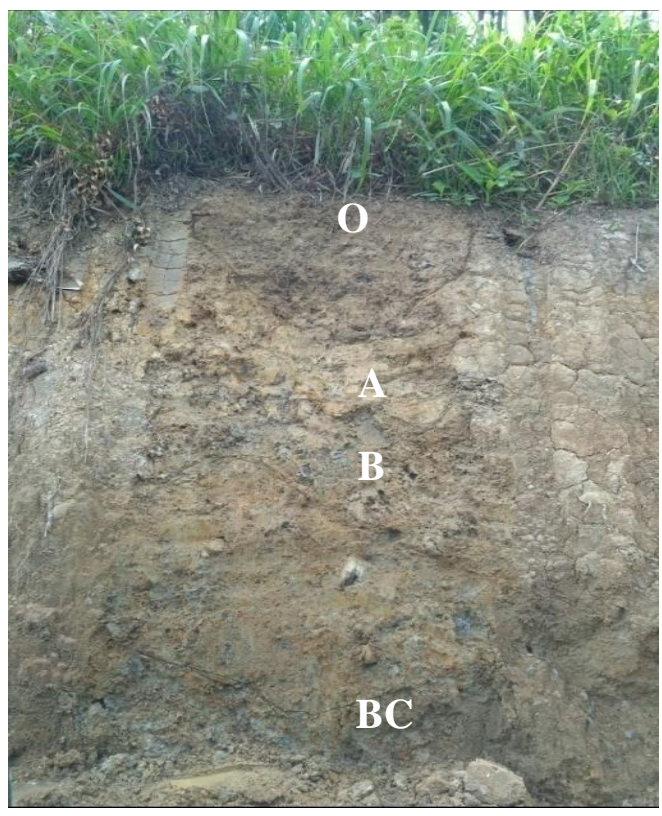

Gambar 2. Pedon II

Penyusunan taksa dimulai dari tingkatan taksa yang tinggi ke tingkatan taksa yang rendah dengan urutan ordo, sub ordo, great group, sub group dan famili. Hasil klasifikasi tanah kebun sere wangi Kabupaten Gayo Lues disajikan pada Tabel 4 
Tabel 4. Klasifikasi Tanah Kebun Sere Wangi Kabupaten Gayo Lues

\begin{tabular}{|c|c|c|c|c|c|}
\hline $\begin{array}{l}\text { Horison/ } \\
\text { Ketebalan } \\
(\mathrm{cm})\end{array}$ & Epipedon & $\begin{array}{c}\text { Horison } \\
\text { Penciri } \\
\text { Bawah }\end{array}$ & $\begin{array}{c}\text { Rezim } \\
\text { Kelembaban }\end{array}$ & & $\begin{array}{c}\text { Nama Tanah } \\
\text { (Ordo - Subgroup) }\end{array}$ \\
\hline \multicolumn{6}{|c|}{ Pedon I } \\
\hline $\mathrm{O}(15)$ & \multirow{4}{*}{ Okrik } & & \multirow{4}{*}{ Udik } & Ordo & : Ultisols \\
\hline $\mathrm{A}(50)$ & & & & Subordo & : Humults \\
\hline $\mathrm{Bt}_{1}(70)$ & & \multirow{2}{*}{ Argilik } & & Great group & : Haplohumults \\
\hline $\mathrm{Bt}_{2}(25)$ & & & & Subgroup & : Typic Haplohumults \\
\hline \multicolumn{6}{|c|}{ Pedon II } \\
\hline $\mathrm{O}(8)$ & \multirow{4}{*}{ Okrik } & \multirow{4}{*}{ Kambik } & \multirow{4}{*}{ Udik } & Ordo & : Inceptisols \\
\hline A (33) & & & & Subordo & : Aquepts \\
\hline B (51) & & & & Great group & : Endoaquepts \\
\hline $\mathrm{BC}(69)$ & & & & Subgroup & : Typic Endoaquepts \\
\hline
\end{tabular}

\section{Pedon I}

Pedon I di Kecamatan Pining memiliki epipedon okrik, karena tidak termasuk defenisi daripada 7 epipedon lain dikarenakan terlalu tipis/kering, mempunyai value warna/chroma terlalu tinggi, mempunyai C-organik sebesar 5,67\% dengan value warna lembab 4 dan chroma 6 yaitu Dark Yellowish Brown (10 YR 4/6). Horison penciri bawah pedon ini memenuhi sebagai horison argilik dikarenakan horison ini memiliki tanda iluviasi liat dengan kandungan $15-40 \%$ dan liatnya 1,2x lebih tinggi daripada horison eluviasi. (Soil Survey Staff, 2014). Menurut Kunci Taksonomi Tanah pedon ini termasuk ke dalam ordo Ultisol karena dijumpai $\mathrm{KB} \mathrm{pH} 8,2 \leq 35 \%$ horison argilik di dalam 1,8 m. Tingkat Sub ordo pedon ini termasuk ke dalam Humults karena karbon organiknya sebesar $\geq 0,9 \%$ di dalam $15 \mathrm{~cm}$ bagian atas horizon argilik/kandik. Tingkatan Great group pedon I termasuk Haplohumults karena Humults yang lain. Tingkat subgrup pedon ini termasuk ke dalam Typic Haplohumults karena Haplohumults yang lain.

\section{Pedon II}

Tanah ini memenuhi kriteria epipedon okrik karena epipedon mencakup horison A atau Ap yang memiliki nilai value warna dan chroma rendah, tetapi terlampau tipis untuk ditetapkan sebagai epipedon molik atau umbrik dan fraksi tanah halusnya memiliki kalsium karbonat eqivalen kurang dari 15 persen. Epipedon okrik juga mencakup horison bahan organik yang terlampau tipis untuk memenuhi persyaratan epipedon histik atau folistik. Pedon ini memiliki horison penciri bawah kambik karena memiliki kriteria kelas tekstur lebih halus yaitu liat dan tidak mengalami kondisi aquic dikedalaman $50 \mathrm{~cm}$ daripada permukaan tanah (telah didrainase) dan warna lembab juga terdapat struktur tanah (tidak memiliki struktur batuan) yang termasuk stratifikasi halus tebalnya $\leq 5 \mathrm{~mm}$, pada $\geq 1 / 2$ volume tanah, dan terdapat chroma lebih tinggi value warna lebih tinggi dan hue lebih merah yaitu $10 \mathrm{YR}$ $5 / 4$. Ordo yang dimiliki adalah Inceptisol dikarenakan memiliki horison kambik yang batas atasnya di dalam $100 \mathrm{~cm}$ dari permukaan tanah mineral dan batas bawahnya pada kedalaman $25 \mathrm{~cm}$ atau lebih di bawah permukaan tanah mineral. Subordo pada pedon ini memenuhi kriteria Aquepts karena pada lapisan di atas kontak litik di dalam $40 \mathrm{~cm}$ dan $50 \mathrm{~cm}$ dari permukaan tanah mineral yang mana saja lebih dangkal, dan memiliki kondisi akuik. Pedon ini memiliki kriteria great group Endoaquepts karena Aquepts yang lain. Subgrup pada pedon ini Typic Endoaquepts karena Endoaquepts yang lain. 


\section{KESIMPULAN DAN SARAN}

Podsolik Coklat pedon I memiliki epipedon okrik dan horison penciri bawah argilik, kemudian diklasifikasikan ke dalam Sistem Taksonomi Tanah menjadi (ordo Ultisol, subordo Humults, great group Haplohumults, dan subgrup Typic Haplohumults). Inceptisol pedon II memiliki epipedon okrik dan horison penciri bawah kambik kemudian diklasifikasikan ke dalam Sistem Taksonomi Tanah menjadi (ordo Inceptisol, subordo Aquepts, great group, dan subgrup Endoquepts Typic Endoquepts). Perlu dilakukan penelitian lanjut sampai ke tingkat famili.

\section{DAFTAR PUSTAKA}

Badan Perencanaan Pembangunan Daerah Kabupaten Gayo Lues. 2018. Rencana Pembangunan Jangka Panjang Daerah Kabupaten Gayo Lues Tahun 2005-2025 (Qanun No. 17 Tahun 2007). Badan Perencanaan Pembangunan Daerah, Gayo Lues.

Hardjowigeno, S. 2003. Klasifikasi Tanah dan Pedogenesis. Akademika Pressindo, Jakarta.

Soil Survey Staff. 2012. Kunci Taksonomi Tanah. Edisi. Pusat Penelitian Tanah dan Agroklimatologi.

Sumiartha, K., N. Khodrata., N.S. Antara.2012. God agriculture practice - tanaman sereh. Publikasi Projek Kurikulum. Universitas Udayana Bali. 